\title{
Sakson Gramatik: Zgodovina Dancev Nekaj zanimivih pričevanj
}

\author{
Prevedla Aiša Napast
}

Gesta Danorum Saksona Gramatika so eno najpomembnejših besedil srednjeveške danske književnosti. Prvih devet knjig opisuje predvsem legendarno zgodovino, zato so bogat vir skandinavskih mitov. Pri Zgodovini Dancev služi dolga lista kraljev kot nekakšno ogrodje, kronološka hrbtenica, ki se razširi v razne eksemplarne pripovedi o moralno dobrem in slabem, stare legende, dele islandskih sag, govore iz herojskih pesmi ter racionalizirane mite. Te pripovedi prikazujejo kralje, njihovo dinastično legitimnost in vojaške sposobnosti, hkrati pa so pomembne tudi zaradi opisov drugih slojev družbe, žensk in bogov. Delo je razdeljeno na predgovor in šestnajst knjig, od katerih začuda štirinajsta obsega več kot četrtino dela. Ta razporeditev je zelo verjetno prvotna. Zgodovina Dancev je prozimetron, vendar poezijo vsebuje le prva polovica, torej osem knjig. Nastalo je po naročilu nadškofa Absalona, ki je želel ovekovečiti dejanja Dancev in biti kos podobnim literarnim dosežkom sosednjih narodov. Pripoved je kronološka in se začne s prvim danskim vladarjem, Danom, ustanoviteljem kraljeve dinastije; zaključi pa se $\mathrm{z}$ vladavino Valdemarja I. in njegovega sina Knuta. Tako zajema zgodovino do leta 1185. Število knjig je neobičajno in se oddaljuje od bolj tradicionalnih dvanajstih; morda se je avtor pri tem zgledoval po Pavlu Diakonu in njegovem delu Historia Romana.

O avtorju nam je zatrdno znano le malo, še največ namigov nam ponudi sam v predgovoru Zgodovine Dancev, kjer omenja svojo vlogo v spremstvu nadškofa Absalona. Ta je bil mogočna cerkvena osebnost svojega časa in je v Lundu kot nadškof v letih 1177-1201 načeloval velikemu dvoru ter bil eden kraljevih najbližjih svetovalcev. Lund je bil v poznem desetem stoletju ustanovljen na jugu Švedske, vendar je takrat ta pokrajina pripadala Danski. Kmalu je postal pomembno krščansko središče baltske in skandinavske 
regije. Absalon, ki je bil torej Saksonov delodajalec, ga omenja v oporoki kot svojega tajnika (clericus). Zelo verjetno je, da ga lahko istovetimo tudi s sočasnim kanonikom Saksonom, ki je bil član tamkajšnjega kapitlja. Na neki Absalonovi listini je podpisan magister Saxo, kar pomeni, da je bil morda avtor tudi učitelj v katedralni šoli. Sakson sam je izviral iz vojaške družine, ki je danskim kraljem služila že generacije. To lahko razberemo iz predgovora, $\mathrm{v}$ katerem svoje delo posveti kralju Valdemarju II (1202-1241) z besedami, da se bo zanj sicer bojeval, kot so se za kralje njegovi predniki, namesto orožja pa bo pri tem uporabljal svoj um. Kakor Absalon naj bi izhajal iz Zelandije, največjega danskega otoka. Prav tako kot ostale informacije tudi čas rojstva in smrti ocenjujejo na podlagi dedikacij in sočasnih dogodkov, ki jih omenja $\mathrm{v}$ predgovoru, iz česar se posredno sklepa, da je Zgodovino Dancev pisal dvajset let, približno med 1188 in 1208 . Rodil naj bi se najkasneje leta 1163 , ne vemo pa, koliko let po dokončanju Zgodovine je še živel.

Avtorja lahko dojemamo kot predstavnika tistih srednjeveških piscev, katerih dela so pripadala zvrsti origo gentis. Sam omenja Cerkveno zgodovino angleškega ljudstva Bede Častitljivega in Zgodovino Langobardov Pavla Diakona. Ta in podobna dela so Saksona Gramatika zagotovo navdahnila, da je sledil zgodovini Dancev od legendarnih začetkov do svojih dni. Srednjeveški zgodovinopisci so imeli za glavni namen svojega pisanja moralno izobraževanje svojih bralcev, kar izhaja že iz antike. V veliki meri jih vodi prepričanje, da je zgodovina več kot le opis preteklih dejanj, namreč tudi zbirka moralnih in političnih nasvetov. Sam Sakson se pogosto zgleduje po moralizirajočih klasičnih avtorjih, recimo Valeriju Maksimu, ki je tudi sicer njegov najpomembnejši lingvistični vzornik. ${ }^{1}$

Pričujoče skromne odlomke iz Zgodovine Dancev sem izbrala, ker pomembno bogatijo sicer fragmentarno poznavanje nordijske mitologije in verskih običajev - opisujejo poganske bogove in njihove posle z danskimi kralji in heroji, magijo, prerokbe, versko središče v Uppsali, žrtvovanja in pogrebne običaje. Sakson racionalizira mite in tako bogove razlaga kot posebej nadarjene in slavne osebe iz daljne preteklosti, ki so jih ljudje začeli po božje častiti. Njegove zgodbe so sicer pogosto zmedene, ponavljajoče se in nekoliko jih kvari moraliziranje. Kot kristjan na poganske bogove gleda $z$ neodobravanjem in jih posledično prikazuje $\mathrm{z}$ veliko mero ostre kritike oziroma tako, da se bralcu zdi neverjetno, da bi takšna oseba sploh lahko bila božanska. Kljub temu gre za dragocena pričevanja, ki prihajajo iz okolja, kjer je poganska vera dolgo vztrajala.V odlomkih lahko opazimo tudi vzporednice $\mathrm{z}$ antično književnostjo in miti, recimo potovanje v podzemlje (Orfejeva, Enejeva katabaza), ki so zagotovo tudi posledica tega, da je bil Sakson klasično izobražen.

1 Podatki o avtorju in delu povzeti po Friis-Jensen, Karsten in Peter Fisher, Saxo Grammaticus Gesta Danorum: Volume 1 (Oxford: Clarendon Press, 2015), I-LXXX, in Fisher, Peter in Hilda Ellis Davidson, Saxo Grammaticus: The History of the Danes books I-IX, Volume II: Commentary (Cambridge: D. S. Brewer, 1980), 1-16. 
Zaradi pogostih eksurzov in vloženih zgodb sem bila primorana sledeče odlomke vzeti iz konteksta, ki ga po potrebi na kratko razlagam.

\section{PROLOG}

Pr.1.3 Ne bi rad, da bi bralec prezrl, kako so stari Danci v želji, da bi ohranili spomin na slavo znamenitih junaštev, posnemali pesništvo $\mathrm{v}$ rimskem slogu. Ne le da so opevali veličastne podvige, ${ }^{2}$ temveč so poskrbeli tudi, da so bili dosežki prednikov, ki so jih poznali iz ljudskih pesmi v maternem jeziku, $\mathrm{v}$ njihovih pismenkah vklesani v kamne in skale. ${ }^{3}$ Sledil sem stopinjam teh pesmi, kakor da bi šlo za antične spise, in poskrbel, da sem prenesel njihov pomen, ko sem jih prevajal verz za verzom. ${ }^{4}$ Naj se ve, da je moja kronika osnovana na starodavnih pričevanjih, ne na nedavnih izmišljotinah, saj pričujoče delo ponuja zanesljivo znanje o nekdanjih časih, ne pa bleščavo in izumetničeno govoričenje. Nadalje pomislimo, koliko pripovedi bi zapisali ti nadarjeni ljudje, če bi svojo žejo po pisanju tešili ob znanju latinskega jezika. Kljub pomanjkanju znanja latinščine je bila njihova želja po tem, da bi zapustili spomin na svoja dejanja, tako velika, da so namesto zvitkov uporabili velikanske kamne in si za rabo knjig izposodili skale.

\section{PRVA KNJIGA ZGODOVINE DANCEV}

Večinoma je govor o podvigih Hadinga, prvega izmed vikinških vladarjev, ki jim Sakson v Zgodovini novelistično nameni celoten življenjepis. Otroštvo naj bi preživel pri velikanih, ko pa je bil oropan njihove zaščite, se ga je usmilil enooki starec (ki ga je moč prepoznati kot Odina) in mu pomagal doseči slavo ter maščevati očeta. Skozi knjigo je poudarjena Hadingova privrženost Odinu, zato avtor nekaj odlomkov nameni tudi opisu bogov.

1.5.2 Da se ne bi zdelo, da predrzno nasprotujem javnemu mnenju ali resnici dodajam dejstva, ki presegajo verodostojnost, je vredno vedeti, da so nekdaj tri vrste magov vsaka s svojimi zvijačami izvajale nepredstavljive čudeže. ${ }^{5}$

1.5.3 Prvi izmed teh so bili možje nadnaravne velikosti, ki so jih ljudje $\mathrm{v}$ preteklosti imenovali velikani in so človeško postavo presegali z izjemno velikostjo.

2 Avtor je bil seznanjen s staro nordijsko ustno pripovedno tradicijo.

3 Govor je torej o runskih napisih.

4 Sakson se sklicuje na svoje prevode in priredbe ljudskih pesnitev, ki jih je uporabil v knjigah I-VIII.

5 Tukaj se prične Saksonova prva digresija o bogovih predkrščanske Skandinavije. Prvega izmed rodov, ki jih Sakson omenja, lahko prepoznamo kot velikane (izvirno Jötnar), drugega kot aze (izvirno Æsir), tretjih pa ne moremo prepoznati z gotovostjo, verjetno gre za vane (izvirno Vanir), skupino božanstev, ki so jih povezovali z rodovitnostjo. 
1.5.4 Naslednji so bili tisti, ki so prvi osvojili veščino prerokovanja in so imeli v oblasti vedeževalsko umetnost. Ti so po postavi zaostajali za prej omenjenimi, a so jih tem bolj prekašali po živahnejših umskih zmožnostih. Med temi in velikani so se bíle nenehne bitke za oblast, dokler si niso magi v boju podjarmili rodu velikanov in si prisvojili ne samo pravice do vladanja, temveč celo sloves božanskosti. Oboji so bili nadvse vešči prevar, ki so zavajale oči: svoje in tuje obraze so znali skriti za različnimi podobami in z lažnim videzom zakrivati oblike resničnosti.

1.5.5 Tretji so nastali iz medsebojne zveze obeh rodov, vendar niti po telesni velikosti niti po ukvarjanju s čarovniško veščino niso dosegali svojih prednikov. Vseeno pa so ljudje, katerih um so prevarale njihove sleparije, verjeli v njihovo božanskost.

1. 5.6 Ni presenetljivo, da so njihovi nenaravni čudeži pritegnili barbare in da so se le ti prepustili čaščenju neprave vere, saj so bili tudi razsodni Rimljani zavedeni, da so smrtnost nekaterih takšnih ljudi poveličevali z božanskimi častmi. To omenjam zato, da ne bo nejeverni bralec nasprotoval, ko bom obsežno opisoval te iluzije in čudesa.

1.7.1 V tem času je živel neki Odin, ${ }^{6} \mathrm{ki}$ mu je celotna Evropa zmotno pripisovala božansko naravo. Imel pa je navado, da se je precej pogosto odpravil v Uppsalo, ${ }^{7}$ ki jo je bodisi zaradi brezbrižnosti prebivalcev ali zaradi lepe okolice zelo cenil in je v njej rad prebival. Severnjaški kralji so se želeli izkazati z izrazitejšim čaščenjem, zato so dali po njegovi podobi narediti zlat kip, ki je imel tudi roke bogato okrašene s težkimi zapestnicami, in ga kot znamenje svojega spoštovanja in $\mathrm{z}$ vtisom največje pobožnosti poslali $\mathrm{v}$ Bizanc. ${ }^{8}$ Odin je bil vesel tolikšne slave ter je z navdušenjem sprejel privrženost darovalcev. Njegova žena Friga ${ }^{9}$ je dala poklicati obrtnike in poskrbela, da so s kipa sneli zlato, zato da bi lahko okoli hodila bolj okrašena. Odin je dal nato obrtnike obesiti, kip pa je postavil na podstavek in s čudežno veščino nekako dosegel, da se je na človeški dotik odzival z glasom. Toda Friga je kljub temu dajala prednost sijaju svoje oprave pred božanskimi častmi moža in se je pustila oskruniti enemu izmed služabnikov. S pomočjo njegove pretkanosti je uničila kip in je zlato, namenjeno javnemu malikovanju, uporabila za zasebno razkošje. Ni se obotavljala vztrajati v brezsramnosti, da bi čim prej zadostila svoji grabežljivosti. Ženska ni bila vredna, da bi bila deležna božanskosti soproga! Naj na tem mestu dodam še kaj drugega, kakor da je bilo takšno božanstvo vredno takšne soproge? Tako velike so bile zmote, ki so nekoč

6 Pri slovenjenju imen izhajam iz njihovih latiniziranih, ne staronordijskih različic, razen pri Thor in Odin, ker gre za imeni, ki sta v slovenščini uveljavljeni.

7 Nekdanje središče stare vere, kjer so častili predvsem Odina in Freyra, je bilo v drugi polovici dvanajstega stoletja že pod oblastjo krščanskega škofa.

8 V Saksonovem času so bili islandski učenjaki mnenja, da so poganski bogovi azi izvirali iz Male Azije in ena izmed teh učenih teorij postavlja Odinovo prvotno bivališče v Bizanc. V: Fisher in Davidson, Saxo Grammaticus 1980, 32.

9 Lat. Frigga, izvirno Frigg. 
smešile bistroumnost smrtnikov. Odin, ki je bil ogorčen nad obema ženinima razžalitvama, je zaradi uničenja svoje podobe trpel skoraj prav toliko kot zaradi pregrehe čez zakonsko posteljo. Zato se je prizadet zaradi dvojne izdaje poln iskrenega sramu odločil za pregnanstvo in menil, da bo na ta način opral sramoto, ki je omadeževala njegov ugled.

1.7.2 Njegov odhod je bil kakor božji dar za nekega Mitodina in je tega znanega prevaranta spodbudil, da je izrabil priložnost ter se pretvarjal, da je božanstvo. Sloves, ki so mu ga prinesle njegove zvijače, je barbarom zatemnil um z novimi zmotami in jih napeljal, da so z obredi častili njegovo ime. Trdil je, da $z$ neurejenimi skupinskimi daritvami ni mogoče pomiriti jeze bogov ali se pokoriti za kršitev božje volje; zato je preprečil, da bi se jim žrtvovalo skupaj, in je odredil ločeno darovanje posameznim bogovom. Ko se je Odin vrnil, je Mitodin opustil svoje trike in odšel v Feonijo, ${ }^{10}$ da bi se skril. Tam pa so ga prebivalci napadli in ubili. Njegova podlost je bila očitna celo po njegovi smrti. Če se je namreč kdo približal njegovemu grobu, je nenadoma umrl; še po smrti je torej širil takšno pogubo, da so se spomini na njegovo smrt zdeli skoraj odvratnejši od tistih na življenje, kakor da bi želel izterjati kazen od krivcev za svojo smrt. To zlo je meščane pripravilo do tega, da so truplo izkopali, mu odsekali glavo in prsi prebodli $\mathrm{z}$ naostrenim kolom. $\mathrm{V}$ tem so ljudje našli rešitev.

1.7.3 Ko si je po smrti svoje žene ponovno pridobil sijaj nekdanje slave in se je zdelo, da je njegovo božanstvo očiščeno sramote, se je Odin vrnil iz pregnanstva. Vse, ki so si v njegovi odsotnosti lastili božanske časti, je prisilil, da so se jim odpovedali, češ da jim ne pripadajo. Združenja magov, ki so nastala $\mathrm{v}$ tem času, je razgnal kakor sence, nad katere je prišel sij njegove božanske narave. Zaustavil pa jih ni le z ukazom, naj se odpovedo hlinjeni božanskosti, temveč jim je velel tudi zapustiti deželo, saj je bil prepričan, da so upravičeno izgnani iz dežele tisti, ki so se tako neupravičeno vsilili med nebeščane.

Avtor se vrne k pripovedi o Hadingovih podvigih. Ko je Hading nekoč plaval, je nevede ubil božanstvo $v$ preobleki morske pošasti, zaradi česar si je nakopal jezo bogov in neka ženska mu je prerokovala, da ne bo našel miru ne na morju ne na kopnem.

1.8.12 Hading je na poti domov trpel, kot je bilo prerokovano, njegov prihod pa je skalil mir $\mathrm{v}$ deželi. Med njegovo plovbo je namreč nastala mogočna nevihta in velikanski vihar je uničil ladjevje. Ko je po brodolomu iskal zavetje, je tisto prebivališče zajelo nenadno opustošenje. Dokler se ni z daritvami pokoril za zločin in se pri bogovih ponovno dobro zapisal, ni bilo zdravila za njegovo nesrečo. Da bi si povrnil naklonjenost bogov, je žrtvoval 
temnopolte žrtve bogu Froju. ${ }^{11}$ Takšen način spravne daritve je ponovil ob vsakoletnem prazniku in ga zapustil potomcem, da so ga posnemali. Sveoni ta praznik imenujejo Froblod.

1.8.13 Ko je po naključju izvedel, da je neki velikan sklenil zaroko $\mathrm{z}$ Regnildo, ${ }^{12}$ hčerjo Hakvina, ${ }^{13}$ kralja Niterijcev, ${ }^{14}$ je bil ogorčen nad nedostojnim dogovorom, ki je obljubljal nesrečen zakon, in je s plemenitim podvigom preprečil zvezo. Odpotoval je v Norvagijo ${ }^{15}$ in odvratnega snubca kraljeve hčere premagal v boju. Četudi bi lahko užival v kraljevskem razkošju, je bolj cenil hrabrost kot brezdelje in je imel za najslajšega vseh užitkov to, da je pred krivicami branil ne le sebe, temveč tudi druge. Čeprav dekle ni poznalo svojega dobrotnika, ki je bil prekrit s številnimi ranami, ga je pazljivo oskrbelo. Da bi ga lahko prepoznala tudi potem, ko bi preteklo nekaj časa, ga je zaznamovala s tem, da mu je v rano na nogi vstavila prstan. Pozneje, ko ji je oče dovolil, da si sama izbere moža, je na gostiji zbrala mladeniče in pozorno pregledala njihova telesa ter pri tem iskala znamenje, ki ga je nekoč shranila. Ko je pri Hadingu opazila dokaz o skritem prstanu, ${ }^{16}$ je ostale odslovila, njega pa objela in mu obljubila zakon, saj ni dopustil velikanu, da si jo pridobi za ženo.

1.8.14 Medtem ko je Hading bival pri njej, se je zgodil izjemen čudež. Ob večerji je pozornost vzbudila ženska blizu ognjišča, ki je nosila cvetove trobelike. Dvignila je glavo s tal in iztegnila roke, pri čemer se je zdelo, da sprašuje, v katerem delu sveta pozimi rastejo tako sveže zeli. Ker je kralj želel to izvedeti, ga je zavila v svoj plašč, ga potegnila s seboj pod zemljo in izginila. Menim, da je bila volja podzemnih bogov, da pride še živ tja, kamor bo primoran odpotovati v smrti. Najprej sta stopila skozi oblak dimaste megle in krenila po poti, ki jo je obrabila dolgotrajna hoja. Zagledala sta ljudi oblečene $\mathrm{v}$ bogata oblačila in plemiče odete v škrlat. Šla sta mimo njih in se naposled približala s soncem obsijanemu kraju, kjer so rasle zeli, ki jih je bila ženska odnesla. Šla sta naprej do prepadne globočine in reke s temačno vodo, na kateri se je v silovitih vrtincih vrtelo orožje različnih vrst; ${ }^{17}$ imela pa je tudi most, da se jo je dalo prečkati. Ko sta prišla čez reko, sta zagledala dve vojski v silovitem medsebojnem spopadu. ${ }^{18}$ Ko se je Hading pri ženski pozanimal

11 Izvirno Frø, drugo poimenovanje boga Freyra, ki so ga častili med drugim kot boga plodnosti.

12 Lat. Regnilda, izvirno Regnhild.

13 Lat. Haquinus, izvirno Håkon, legendarni kralj.

14 Ljudstvo na severu Norveške.

15 Na Norveško.

16 Prepoznavanje po prstanu je znan motiv ljudskih pripovedk.

17 "Z vzhoda srhljiva reka pridre, / skozi strupeno mrzle doline, / same sulice, noži in meči ... / imenuje se Slidr.« Opis reke v Poetični Eddi, Bajanje vidke, 36, prev. Gjuld, Bogdan in Silvin Košak, Edda: Iz staroislandskega epa (Ljubljana: Mladinska knjiga, 2004), 20.

18 Obstaja precejšnje število literarnih poročil o tem, kako je bil tistim, ki so v bitki ali kot prostovoljne obredne žrtve umrli v službi boga Odina, dovoljen vstop v Valhallo. Slika takšnega posmrtnega življenja je povezana z izročilom, da tam poteka nenehna bitka, v kateri se bojevniki (izvirno Einherjar) vojskujejo, nato pa so zvečer obujeni in se gostijo ob pojedini, nakar se boj zjutraj ponovno prične. V: H. R. Ellis Davidson, Gods and Myths of Northern Europe (London: Penguin Group, 1990), 149-153. 
zanju, mu je rekla: »To so tisti, ki so padli pod mečem in nenehno uprizarjajo svojo smrt ter skušajo s tem prizorom posnemati dejanja preteklega življenja«. Odšla sta naprej, a na poti ju je zaustavil težko dostopen in neprehoden zid. Ženska ga je neuspešno poskusila preplezati, kajti niti njeno zgubano suhljato telo ji ni bilo v pomoč, zato je zavila vrat petelinu, ki ga je slučajno nosila s seboj in ga vrgla čez zaporo zidov. Ptič je nemudoma oživel in z glasnim kikirikanjem pričeval o svojem ponovnem obstoju.

1.8.15 Ko se je Hading vrnil, se je s soprogo odpravil v domovino, pri čemer se je s hitro plovbo izognil zasedi piratov, ki so ga ogrožali. Četudi so imeli enakovredne ladje in so jim pomagali skoraj isti vetrovi, ga vendarle niso mogli napasti, ko je rezal valove. ${ }^{19}$

1.8.16 Medtem je Ufi, ki je imel izredno lepo hčer, oznanil, da jo bo dal v zakon tistemu, ki bi ubil Hadinga. Ta kupčija je bila zelo vabljiva za nekega Tuninga, ki je zbral tolpo Bjarmijcev ${ }^{20}$ in skušal doseči obljubljeno nagrado. Hading ga je imel namen prestreči, a, medtem ko je plul mimo Norvagije, je na obali opazil starca, ${ }^{21} \mathrm{ki} \mathrm{mu}$ je mahal s plaščem in tako sporočal, naj pristane. Četudi so se njegovi sopotniki upirali in trdili, da bo preusmeritev pogubna za potovanje, je starca spustil na krov in ga vzel za svetovalca pri ureditvi vojske. Starec je čete skrbno razporedil po metodi, po kateri je bila prva bojna vrsta sestavljena iz dveh, druga iz štirih mož, v tretji je njihovo število naraslo na osem in vsako naslednjo je podvojil glede na prejšnjo. Prav tako je ukazal oddelku pračarjev, naj se s kril vojske umaknejo v zadnjo bojno vrsto, in jih združil z vrstami lokostrelcev. Ko so bile čete tako razporejene v klinasto formacijo, se je sam postavil za bojevnike in iz vrečice, ki jo je imel obešeno okoli vratu, izvlekel samostrel. Ta je bil sprva videti droben, kmalu pa se je napel v širokem loku. Starec je na tetivo nataknil deset puščic, ki jih je vse hkrati v krepki plohi naperil zoper sovražnike, in jim zadal prav tolikšno število ran. Bjarmijci so nato nadomestili orožje z zvijačami. Z zaklinjanjem so razparali nebo v oblake ter vedrino neba skazili s turobnim vršanjem naliva. $\mathrm{V}$ odgovor je starec nastalo oblačno maso zajezil s svojim oblakom in s to oviro ustavil naliv. Hading je zmagal in ob odhodu mu je starec napovedal, da ne bo umrl zaradi nasilja sovražnikov, temveč po lastnem vzgibu. ${ }^{22}$ Ukazal mu je tudi,

19 To lahko razumemo tako, da Hading s tem, ko se Freyru odkupi za poboj morskega božanstva, pridobi posebne moči nad morjem in lahko pobegne. Vzporednica z antičnimi junaki, ki jim veter ni bil naklonjen zaradi srda bogov.

20 Bjarmaland, Bjarmija: regija na severu Rusije, vzhodno od Belega morja.

21 Ponovno gre za Odina, ki je bil tudi bog vojne.

22 Hading se obesi, kar ga še bolj povezuje z Odinom in ga prikazuje kot njegovega izbranca. Odin je po tradiciji namreč bog obešencev, ker se je tudi sam ritualno obesil na jesen Yggdrasil, kozmično drevo, da bi si s takšno iniciacijo in simbolično smrtjo pridobil skrito znanje. V: Davidson, Gods and Myths of Northern Europe, 140-145. Pomembna epizoda, ki jo opisuje Sakson (6.5.6-7), je tudi smrt kralja Vikarja. Ta je bil z možmi na pomorski ekspediciji in nadaljevanje poti so jim dolgo časa onemogočale hude nevihte, zato so se odločili bogove pomiriti s človeškim žrtvovanjem. Žreb je za žrtev določil kralja in z možmi so se dogovorili za ritualno uprizoritev njegove smrti z obešanjem, vendar je Odin izterjal smrt, ki mu je pripadala. Obsežneje v Lawrence Eson, »Odin and Merlin: Threefold Death and the World Tree«, Western Folklore 69, št. 1 (2010): 85-107. 
naj daje prednost veličastnim bojem $\mathrm{v}$ daljnih deželah pred nepomembnimi obmejnimi spopadi.

\section{TRETJA KNJIGA ZGODOVINE DANCEV}

Tretja knjiga opisuje vladavino kraljev Hoterja in njegovega sina Rorika. Prvi del knjige se osredotoča na rivalstvo med Hoterjem in Balderjem, kiga tekmec naposled ubije. To je Saksonova evhemeristična različica zgodbe, ki jo bolje poznamo iz Prozne Edde (avtor Snorri Sturluson), kjer Balderja z zvijačo ubije Loki, in zato izvrstna priložnost za opazovanje razlik $v$ interpretaciji. Tradicionalna različica mita je naslednja: ${ }^{23}$ Balder, Odinov sin (ki naj bi bil najlepši med bogovi, milosten in moder $)^{24}$ je imel zlovešče sanje in Frigg je od vseh živih bitij in stvari na Zemlji izsilila obljubo, da mu ne bodo škodovala. Prevarantski in pogubni bog Loki izve, da samo mala rastlina bele omele ni pod prisego, ker se je Frigg zdela premajhna, da bi lahko poškodovala njenega sina. V svoji hudobiji Loki prepriča Balderjevega slepega brata Hoderja, da proti bratu ustreli puščico bele omele, in ta se zruši mrtev. Bogovi ga položijo na pogrebno grmado na njegovi ladji, ob njega položijo njegovo ženo Nano, ki je umrla od žalosti, in njegovega konja ter jih skupaj zažgejo na morju. Bogovi v svoji bridkosti pošljejo boga Hermoda v podzemlje $k \mathrm{Hel}$, da bi umrlega vrnila med žive. Boginja smrti Hel to odobri pod pogojem, da bodo vsa bitja jokala za izgubljenim bogom. Res vsi žalujejo, le neka velikanka prošnjo zavrne in bogovi ugotovijo, da je to $v$ resnici Loki v preobleki. Ta besu bogov tokrat ne more uiti in kaznovan je s tem, da ga privežejo na skalo in da se nad njim dviga kača, katere strup pada na njegov obraz. Tam mora ostati do Ragnaroka, padca bogov, ko bo svet prerojen. Takrat se bo Balder vrnil iz podzemlja in zavladal novemu rodu bogov.

3.1.1 Za Hiartvarom je vladavino v obeh kraljestvih prevzel Hoter ${ }^{25}$ ki je bil z bratom Atislom rejenec kralja Gevarja. Njegov čas bom bolje opisal, če bom pričel na začetku njegovega življenja. Če prvih let njegove življenjske poti ne obsodimo na molk, lahko lepše in celoviteje opišemo njegova poslednja leta.

3.2.1 Potem ko je Helgon ubil njegovega očeta Hodbroda, je Hoter preživel otroštvo v skrbništvu pri kralju Gevarju. Ko je odraščal, je svoje sorejence

23 Davidson, Gods and Myths of Northern Europe, 35-38. Gre za islandsko-norveško tradicijo tega mita. Tudi v Saksonovo različico je vpleten nadnaravni svet in v glavnih točkah avtorja uporabita zelo podobne motive: Balder ima preroške sanje, ima naklonjenost Odina in ostalih bogov, nadnaravne sile mu obenem pomagajo in se mu zoperstavljajo; ubit je s posebnim orožjem, ker velja za neranljivega.

$24 \mathrm{Ni}$ zgodnjih dokazov o Balderjevem kultu, aspekti mita so v splošnem zelo kontroverzni in temu primerno je veliko poskusov rekonstrukcij in umestitev Balderja v verovanje. Za osnovni pregled različnih tez gl. Anatoly Liberman, »Some Controversial Aspects of the Myth of Baldr", Alvíssmál: Forschungen zur mittelalterlichen Kultur Skandinaviens 11 (2004): 17-54.

25 Lat. Hotherus, izvirno Høther, legendarni kralj Švedske in Danske. 
in vrstnike prekašal po neverjetni telesni moči. Obdarjen pa je bil tudi s številnimi talenti duha.Vsekakor je bil v plavanju, lokostrelstvu in boksu prav tako okreten in vešč kot katerikoli njegov vrstnik ter bil enako izurjen kakor močan. Nezrelost svojih let je presegel s številnimi odlikami duha. Nihče ni bil bolj vešč izvajalec na harfi ali lutnji. Poleg tega je bil izkušen tudi v igranju na plunko, liro in gosli. Z različnimi ritmi je lahko privedel ljudi do kateregakoli razpoloženja. Smrtnike je znal navdahniti z veseljem, žalostjo, sočutjem ali sovraštvom. Tako je s tem, kar je njihovim ušesom nudilo užitek ali vzbujalo grozo, prevzel njihove duše.

3.2.2 Vse te mladeničeve spretnosti so ugajale Gevarjevi hčeri Nani, ki se je zato zaljubila v Hoterja. Zgodi se namreč, da junaštvo mladeničev navduši dekleta, ki jih pritegne njihova vrlina, čeprav jim po videzu manj ugajajo. Ljubezen namreč pozna številne pristope. Nekaterim pot do naklonjenosti odpre lepota, drugim pogum, tretjim pa spretnost v veščinah. Eni si pridobijo veliko ljubezen s prijaznostjo, še več pa jih je zaželenih zaradi sijajnega ugleda; in pogum ne zada dekletom nič blažjih ran kakor lepota.

3.2.3 Pripetilo pa se je, da je Odinovega sina Balderja vznemiril pogled na Nano, ko se je kopala, in pograbilo ga je neizmerno hrepenenje. Razvnela ga je sijajnost njenega prelepega telesa in dušo mu je podžigala očitna lepota njene postave. Kajti lepota je najučinkovitejša spodbuda za poželenje. Da ga ne bi nič oviralo, ko bi hotel zadovoljiti svoje poželenje, je sklenil z mečem pokončati Hoterja, za katerega se je bal, da bo najbolj nasprotoval njegovemu nestrpnemu hrepenenju.

3.2.4 Približno ob tem času je Hoter med lovom pomotoma zašel v megli in naletel na kočo, kjer so bivale gozdne nimfe. ${ }^{26}$ Pozdravile so ga po imenu in vprašal jih je, kdo so. Oznanile so, da s svojim vodenjem in blagoslovi usmerjajo predvsem bojno srečo. Pogosto so bile namreč nevidno navzoče na bojiščih in so s skrivno pomočjo izbrancem prinesle želeni uspeh. Omenile so, da lahko naklonijo srečen izid ali poraz, kakor se jim zljubi. Povedale pa so mu tudi, kako zelo se je Balder ogrel za Nano, ko jo je videl pri kopanju. Toda opozorile so ga, naj ga ne izzove na boj, četudi je vreden njegovega najbolj gorečega sovraštva. Razodele so, da je Balder polbog, ki je bil skrivaj spočet iz božanskega semena. Brž ko je Hoter to izvedel, je bivališče izginilo in spoznal je, da se je nepričakovano znašel pod milim nebom sredi polja. Presenečen pa je bil predvsem nad hitrim izginotjem deklet, nad spremembo kraja, kjer se je nahajal, in nad varljivim videzom domovanja. Ni namreč vedel, da je bilo to, kar se je zgodilo okoli njega, zgolj farsa in ničeva zvijača magije.

3.2.5 Ob svoji vrnitvi je Gevarju po vrsti razložil, kako je zašel, mu povedal za ukane, ki so temu sledile, in nato nemudoma prosil za roko njegove hčere. Gevar je odvrnil, da bi rade volje podprl to zvezo, če se ne bi bal, da si bo z 
zavrnitvijo nakopal Balderjevo jezo, kajti tudi ta se je nanj obrnil s podobno prošnjo. Zatrdil je, da ga zaradi svete moči njegovega telesa ni mogoče pokončati z nobenim orožjem. Dodal je, da ve za meč, ki bi Balderju lahko zadal smrt, vendar pa je ta zaščiten s številnimi ovirami. V lasti ga ima namreč gozdni satir ${ }^{27}$ Miming. Slednjemu pripada tudi zapestnica, ki ima nenavadno skrivno moč, da lastniku poveča premoženje. Poleg tega je dostop do teh krajev oviran in poln preprek ter težko dostopen smrtnikom; večji del poti človeka pesti hud mraz. Zatorej je Gevar Hoterju naročil, naj v sani vpreže jelene, da bo s pomočjo njihove izredne hitrosti prišel čez poledenela slemena. Ko bo prispel tja, mora postaviti svoj šotor stran od sonca tako, da bo prestregel senco votline, $\mathrm{v}$ kateri je imel Miming navado bivati. Obenem pa šotor ne sme zasenčiti votline, da ne bi nenavadna zatemnitev odvrnila satira od tega, da bi stopil ven. Na ta način bo neovirano prišel tako do zapestnice kot do meča; prvo spremlja bogastvo, drugega pa vojna sreča, oba pa prinašata neznansko korist lastniku.

3.2.6 To je dejal Gevar. Hoter ni odlašal in se je ravnal po njegovih navodilih. Potem ko se je utaboril, kakor mu je bilo rečeno, je noči preživljal v skrbeh in dneve ob lovu. Menjavo obeh časov je prestal čuječ in buden, ločitev med svetlobo in temo pa je zaznamoval le s tem, da je eno posvetil premišljevanju in drugo namenil nabiranju živeža. Nekoč pa, ko je bil utrujen, ker so ga vso noč prevzemale skrbi, je satirova senca po naključju padla na šotor. Hoter ga je napadel s kopjem in ga $z$ udarcem premagal ter zvezal, da ni bil več zmožen pobegniti. Nato $\mathrm{mu}$ je $\mathrm{z}$ nadvse surovimi besedami zagrozil $\mathrm{z}$ najhujšim ter zahteval meč in zapestnico. Satir ni okleval in mu je v zameno za svoje življenje dal zahtevano. Tako velika je prednost življenja pred vso lastnino, smrtnikom namreč ni nič dražje od življenjskega diha. Hoter, ki ga je osrečil majhen, a pomemben izplen, se je zadovoljen s pridobljenim bogastvom vrnil domov.

Kralj Sasov, Gelder, napade Hoterja, da bi dobil čudežno zapestnico in meč, vendar ga ta spretno premaga. Nato Helgiju, kralju Halogije, pomaga osvojiti finsko princesoToro.

3.2.9 Medtem ko se je to dogajalo v Halogiji, ${ }^{28}$ je Balder oborožen prišel na Gevarjevo ozemlje, da bi se polastil Nane. Gevar mu je naročil, naj za mnenje povpraša kar Nano samo, zato se je Balder nanjo obrnil s premišljeno očarljivimi besedami. Ker pa je ni mogel prepričati v svoj prid, je vztrajal pri tem, da izve vzrok njene zavrnitve. Odgovorila je, da se bog ne more poročiti s smrtnico, saj bi velikanska razlika $\mathrm{v}$ njuni naravi onemogočala skladno zvezo; da imajo poleg tega bogovi včasih navado razveljaviti dogovorjeno in da nenadoma presekajo vezi, ki so jih sklenili z manjvrednimi. Med različnimi 
partnerji tudi ni stanovitnosti, ker sreča podrejenega $\mathrm{v}$ zvezi z imenitnejšim zmeraj zbledi. Dodala je, da bivata izobilje in pomanjkanje v različnih šotorih in da med sijajem bogastva in neslavnostjo revščine ni trdne zveze tovarištva. Nazadnje je dejala, da se zemeljsko ne veže z nebesnim, ker ju razdvaja tolikšna razlika v izvoru in naravi, da je smrtnik neskončno oddaljen od imenitnosti božje veličine. S temi pretkanimi odgovori je spodnesla Balderjeve prošnje in mu preudarno napletla razloge za zavrnitev.

3.2.10 Ko je Hoter vse to izvedel od Gevarja, se je Helgiju zelo pritoževal nad Balderjevo predrznostjo. Oba sta bila negotova glede tega, kaj bi bilo treba storiti in sta o tem na veliko razpravljala. V nesreči namreč prijateljski pogovor zmanjša bridkost, četudi ne odpravi nevarnosti. Sla po pogumnih dejanjih je prevladala nad drugimi hrepenenji in Hoter se je spustil v pomorsko bitko z Balderjem. Človek bi si mislil, da so se ljudje bojevali proti bogovom, kajti na Balderjevi strani so se vojskovali Thor, Odin in vojska svetih bogov. Tu si lahko videl bitko, v kateri so se pomešale božanske in človeške vojaške sile. Vendar je Hoter, oblečen v tuniko, ki je odbijala orožje, prodrl skozi najbolj strnjene bojne vrste bogov in napadal s tolikšno silo, kolikor je pač lahko uporabi smrtnik proti bogovom. Obenem pa je tudi Thor z neverjetnimi zamahi gorjač ${ }^{29}$ razbijal vse ščite, ki so se mu postavili v bran, sovražnike je pozival k napadu prav toliko, kot je tovariše klical k obrambi. Ni bilo oklepa, ki bi vzdržal njegove udarce in nihče jih ni mogel varno prestreči. Porazil je vsakogar, čigar udarec je odbil. Ne ščiti ne čelade niso vzdržali sile njegovega udarca. Nikomur ni bila $v$ zaščito še tako silna telesna moč. Zaradi tega bi zmaga pripadla bogovom, če ne bi Hoter, čigar četa se je začela umikati, hitro pritekel in onesposobil kij tako, da mu je odrezal ročaj. Potem, ko je bilo orožje neuporabno, so bogovi pri priči zbežali. Proti pričakovanjem je, da bi ljudje premagali bogove, vendar imamo o tem stara pričevanja. »Bogovi« pa pravimo bolj zaradi domneve kot resnice in »božanstva « jih imenujemo zaradi ljudske navade, ne pa zaradi njihove narave.

3.2.11 Sicer pa se je Balder pognal $v$ tek in se $\mathrm{z}$ begom rešil. Četudi so zmagovalci njegove ladje ali razkosali $\mathrm{z}$ meči ali potopili v morju, niso bili zadovoljni s tem, da so premagali bogove, temveč so preostalemu ladjevju sledili s tolikšno togoto, kakor da bi si hoteli z njegovim uničenjem potešiti krvoločno bojno slo. Tolikšen uspeh pogosto vzbudi nezmernost. O bitki priča pristan, ki nosi ime po Balderjevem begu. Kralja Sasov - Gelderja, ubitega v istem boju, je Hoter položil $\mathrm{k}$ truplom njegovih veslačev in ga na grmadi, postavljeni iz ladij, pokopal z zelo lepim pogrebnim obredom. Ne le da je njegov pepel kot kraljeve posmrtne ostanke položil v imenitno grobnico,

29 Po tradiciji je Thorovo kladivo Mjollnir prikazano kot najpomembnejše orožje azov, saj jim omogoča, da svoje domovanje Asgard branijo pred velikani. Sakson (13.5.5) drugje opisuje, kako je danski vladar Magnus Nillson leta $1125 \mathrm{v}$ krščanskem zanosu oropal Thorov tempelj na Švedskem in od tam odnesel velika kladiva, ki so jih morda uporabljali za oponašanje grmenja. Gl. H. R. Ellis Davidson, »Thor's Hammer«, Folklore 76, št. 1 (1965): 1-15. 
temveč mu je dostojanstveno izkazal čast tudi $\mathrm{z}$ bogatimi pogrebnimi slovestnostmi. Da ne bi upa na zakonsko zvezo porušile druge nevšečnosti, je zatem Gevarju ponovil svojo prošnjo in si v zakon pridobil Nano, po kateri je hrepenel. Potem ko je Helgija in Toro radodarno počastil, je svojo novo soprogo pripeljal v Svecijo, ${ }^{30}$ kjer so ga vsi tako spoštovali zaradi zmage, kakor so se Balderju posmehovali zaradi bega.

3.2.12 Ko so sveonski velikaši odpotovali v Danijo, ${ }^{31}$ da bi poravnali dajatve, je Hoter, ki ga je ljudstvo kot kraljevega namestnika častilo zaradi znamenitih dosežkov njegovega očeta, nenadoma izkusil, kako nestalna je sreča. Balder, ki ga je bil še pred nedavnim porazil, se je z njim spopadel in ga premagal, tako da je bil prisiljen pobegniti h Gevarju ter je kot vladar izgubil zmago, ki si jo je bil pridobil kot zasebnik. Ker so bili vojaki zmagovitega Balderja onemogli od žeje, je ta globoko razklal zemljo in razkril skrite izvire v tleh, da bi jih poživil $\mathrm{z}$ blagodejno tekočino. ${ }^{32}$ Žejna vojska se je $\mathrm{z}$ vseh strani hlastaje pognala $\mathrm{k}$ vrelcem, ki so izbruhnili. Njihove sledi so vtisnjene $v$ večnost $\mathrm{z}$ imenom in četudi je prvotni vrelec presahnil, verjetno še ni popolnoma izsušen. Balderja so cele noči preganjali zli duhovi v podobi Nane, zaradi česar je zapadel v tako hudo bolezensko stanje, da se ni mogel niti postaviti na noge. Zato se je navadil potovali $z$ dvovprego ali štirikolesnim vozom. Srce mu je navdajala tako silovita ljubezen, da ga je pahnila na rob smrti. Menil je namreč, da je zmaga ničeva, ker mu ni prinesla Nane.

3.2.13 Tudi namestnik bogov Fro si je izbral bivališče nedaleč od Uppsale. ${ }^{33}$ Tam je stari običaj čaščenja, ki je veljal skozi rodove in stoletja, spremenil v zlovešče in gnusno žrtvovanje. Vpeljal je namreč človeške žrtve in se s tem ostudnim darovanjem obračal na bogove.

Saksonova pripoved je kaotična in to mesto uporabi za razlago dinastičnih bojev med Švedsko in Dansko. Hoter izve, da je Danska, do katere je imel dedno pravico, ostala brez vladarja. Dansko ljudstvo ga imenuje za kralja, postane pa tudi vladar Švedske. Z Balderjem se ponovno spopadeta in Hoter zbeži. Ker je bil dvakrat poražen, se ves razočaran poslovi od svojega ljudstva in umakne $v$ samoto. Medtem ko tava po divjini, se mu ponovno nasmehne sreča.

3.3.4 Hoter je taval po najbolj oddaljenih stranpoteh in šel skozi neobljuden gozd ter slučajno odkril votlino, kjer so bivala neznana dekleta. Izkazalo se je, da so tista, ki so mu nekoč poklonila neprebojno tuniko. Ko so ga vprašale, kaj ga je prineslo tja, je odvrnil, da nenaklonjen izid vojne. Zato je preklel

$30 \mathrm{Na}$ Švedsko.

31 Na Dansko.

$32 \mathrm{~V}$ mnogih mitologijah ima vegetacijski bog nadzor nad vodo.

33 Opis predkrščanskega verskega središča v Uppsali iz enajstega stoletja Adama iz Bremna je obsežnejši (4.26), omenja pa zlati tempelj in kipe Freyra, Thora in Odina. V Gesta Hammaburgensis ecclesiae Pontificum (4.27) opisuje, kako so tam živalske in človeške žrtve z obešanjem ob velikem templju žrtvovali ob posebnem prazniku. 
njihovo nezvestobo in pričel nesrečno objokovati svoje okoliščine in žalostno usodo ter tožiti, češ da se je izteklo drugače, kakor so mu bile obljubile. Toda nimfe so mu odvrnile, da je, četudi je redko izšel iz boja kot zmagovalec, kljub temu sovražnikom zadal prav toliko hudega in da uničenje, ki ga je povzročil, ni bilo nič manjše od tistega, ki ga je bil deležen. Sicer pa bo imel veselje ob zmagi na dosegu roke, če mu uspe ukrasti nenavadno okusno hrano, ki je bila zasnovana tako, da poveča Balderjevo telesno moč. Ničesar mu namreč ne bo težko doseči, če se bo le polastil jedače, namenjene okrepitvi sovražnika.

3.3.5 Njihove besede so Hoterja navdahnile s takojšnjim pogumom za napad nad Balderja, četudi bi se lahko zdelo, da je iti nad bogove z zemeljskim orožjem zelo zahtevna naloga. Med njegovimi ljudmi so bili tudi takšni, ki so trdili, da se ne more nekaznovano spoprijeti z bogovi. Toda njegova brezmejna ognjevitost mu je odvzela vse spoštovanje do veličine bogov. Kajti pri junakih razum ne omaja vedno vneme in lahkomiselnost ne podleže nujno razmisleku. Ali pa se je Hoter morda spomnil, da se moč najslavnejših mož lahko izkaže za najbolj negotovo in da neznatna gruda spodnese velik voz.

3.3.6 Na nasprotni strani pa je Balder postrojil Dance in se spustil v boj zoper Hoterja. Potem ko sta obe strani druga drugi povzročili velikanske izgube in razširili skoraj enako uničenje, je noč zaustavila bitko. Okoli tretje nočne straže je Hoter neopažen odšel oprezat za sovražnikom. Zdramile so ga namreč skrbi spričo bližajoče se nevarnosti. Tako močan nemir pogosto ovira telesni počitek in ne dovoljuje pokoja ne telesu ne mislim. Ko je torej Hoter prispel v sovražni tabor, je ugotovil, da so tri nimfe odnesle Balderjevo skrivnostno jed. Hitro jim je sledil - njihov beg so namreč izdajale mokre stopinje - in naposled dospel do njihovega običajnega bivališča. Ko so ga vprašale, kdo je, je odvrnil, da je bard, in to potrdil s preizkusom. Ponujeno liro je uglasil in s trzalico zabrenkal na strune ter začel spretno igrati umirjeno melodijo, ki je prijala ušesom. Tam pa so bile tudi tri kače, katerih strup so nimfe ponavadi uporabljale za močan pripravek, ki so ga v pravem razmerju zmešale v Balderjevo hrano. Pravzaprav je ravno tedaj iz odprtih kačjih žrel bruhal strup in se izlival v jed. Toda tudi Hoterju bi dve izmed nimf iz prijaznosti ponudili jed, če ne bi najstarejša tega preprečila, saj je ugovarjala, da bi Balderja prevarale, če bi njegovemu sovražniku okrepile telesno moč. On pa je odvrnil, da ni Hoter, temveč eden njegovih spremljevalcev. Zato so se ga nimfe usmilile in ga velikodušno pogostile z obilnim obrokom ter ga obdarile s pasom, ki je prinašal zmago.

3.3.7 Ko se je vračal po isti poti, od koder je prišel, mu je prišel nasproti Balder. Hoter mu je prebodel bok in ga na pol mrtvega pahnil na tla. Hoterjevi vojaki so to izvedeli in cel tabor je odzvanjal od veselega in hrupnega vriskanja, medtem ko so Danci odredili javno žalovanje zaradi Balderjeve usode. Ta je čutil, da mu preti neizogibni konec, in je podžgan od bolečine, ki mu jo je povzročala rana, naslednji dan ponovno zaukazal spopad. Medtem ko je besnela bitka, se je dal na nosilih prinesti v boj, da se ne bi zdelo, da neslavno 
umira v šotoru. Naslednjo noč se mu je prikazala Prozerpina, ${ }^{34}$ ki je v snu pristopila $\mathrm{k}$ njemu in naznanila, da ga bo čez tri dni vzela $\mathrm{v}$ svoje naročje. Tu ni šlo za neosnovan privid v sanjah, kajti po treh dneh je Balder podlegel čezmernim bolečinam. Vojska mu je pripravila kraljevski pogreb in njegovo truplo pokopala $\mathrm{v}$ gomili, ki so jo nasuli v ta namen. ${ }^{35}$

\section{ŠESTA KNJIGA ZGODOVINE DANCEV}

V naslednjem odlomku Sakson Gramatik interpretira Norne, nadnaravna bitja, ki odločajo o usodi in ki v grobem odgovarjajo rimskim Tria Fata. Zasledimo pravljični motiv tipa Trnuljčica, ko zadnja izmed rojenic skuša preprečiti srečno napoved svojih družabnic.

6.4.12 Nekdaj so imeli ljudje običaj, da so se glede prihodnosti svojih otrok obrnili na orakelj Park. Fridlev ${ }^{36}$ je nameraval v skladu s tem verskim običajem povprašati za usodo sina Olafa, zato se je slovesno zaobljubil in se v priprošnji približal svetišču bogov. Ko je pogledal v svetišče, je tam opazil tri nimfe, ki so sedele vsaka na svojem sedežu. Prva izmed njih, ki je bila prizanesljivega značaja, je dečku dodelila prijetno zunanjost in veliko naklonjenost ljudi. Druga ga je obdarila s plemenito velikodušnostjo. Toda tretja, bolj zlovoljna in nevoščljiva ženska, ki je prezirala složno dobrohotnost svojih sester, je želela preprečiti njuna blagoslova, zato je dečkovemu značaju dodelila greh skoposti. Tako je blagoslova drugih dveh skazil strup nesrečnejše usode in Olaf je zaradi dvoumnih darov dobil ime po skoposti, združeni z velikodušnostjo. Tako je ta dodatek odvzel vso sladkost velikodušnim darovom pred njim.

Sledi Saksonov tretji ekskurz o poganskih bogovih $v$ Skandinaviji. Na tem mestu jih vzporeja z rimsko-grškim panteonom in se posluži nekoliko nerodnega dokazovanja, da gre za različne osebe.

6.5.3 Nekdaj so živeli ljudje, ki so bili posvečeni v čarodejstvo in sposobni pričarati sijajne privide. To so bili Thor, Odin in precejšnje število drugih, ki so zameglili um preprostih ljudi in si prisvojili vzvišeni položaj božanstev. Po vsej Norvagiji, Sveciji in Daniji so ljudi zapeljali v lažno prepričanje in jih nahujskali, da so jih vneto častili, ter jih tako okužili s svojo sleparijo, ki je imela nanje izjemen učinek. Vpliv njihove prevare se je namreč tako zelo razširil, da so tudi druga ljudstva častila pri njih neko božansko moč in

34 Skandinavska Hel, boginja podzemlja.

35 Odin, ki je bil odločen, da bo svojega sina maščeval, je dolgo snubil princeso Rindo in ta mu je naposled rodila sina, ki je ubil Hoterja.

36 Lat. Fridleuus, izvirno Frithlef, legendarni kralj Danske, član dinastije, o kateri je govor v šesti knjigi. 
jih imela za bogove ali vsaj za njihove družabnike. Tako so ljudje svečano zaobljubljali darove čarodejem in namenili lažnemu krivoverstvu spoštovanje, ki bi ga morali izkazati pravi veri.

6.5.4 Posledica tega je, da pri nas dneve, ki si sledijo v tednu, navajamo z imeni prav teh »bogov«. Znano je namreč, da so jim stari Rimljani dodelili drugačna poimenovanja, izpeljana iz imen bogov oziroma iz sedmih planetov. Iz tega poimenovanja dni je jasno, da osebe, ki so jih častili naši ljudje, niso iste kot tiste, ki so jih stari Rimljani imenovali na primer Jupiter in Merkur in ki so jih v Grčiji in Rimu ponižno častili z vraževernimi obredi. Tista dva dneva namreč, ki ju pri nas imenujemo Thorov ali Odinov dan, oni imenujejo Jupitrov ali Merkurjev dan. Če torej glede na razliko v zaporedju sprejmemo razlago, da je Thor Jupiter in Odin Merkur, in če upoštevamo prepričanje našega preprostega ljudstva, ki verjame, da je Thor Odinov sin, dobimo jasen dokaz, da je Jupiter Merkurjev sin. Rimljani pa so nasprotnega mnenja in trdijo, da je Jupiter spočel Merkurja. Če je njihova trditev resnična, smo lahko prepričani, da je Thor povsem druga oseba kot Jupiter in Odin druga kot Merkur.

6.5.5 Nekateri pravijo, da si bogovi, ki so jih častili pri nas, delijo zgolj ime s tistimi, ki so jih slavili v Grčiji ali Rimu. Trdijo, da so si naši, ki so onim skoraj enakovredni, le izposodili njihovo obredje in poimenovanje. Zdaj pa dovolj razprave o starodavnih danskih božanstvih. Te zadeve sem malce osvetlil, da bi bilo bralcu razumljivo, kakšnim običajem se je naša dežela vdajala $v$ času poganskega vraževerja. 